\title{
PENGGUNAAN VARIABEL DUMMY UNTUK MENINGKATKAN NILAI DETERMINASI FAKTOR EKSTERNAL TERUKUR TERHADAP DURASI
}

\author{
Astrid Dwi Lestari ${ }^{1}$ dan Basuki Anondho ${ }^{2}$ \\ ${ }^{1}$ Program Studi Sarjana Teknik Sipil, Universitas Tarumanagara, Jl.Letjen S. Parman No.1 Jakarta \\ Email: aforastrid@gmail.com \\ ${ }^{2}$ Program Studi Sarjana Teknik Sipil, Universitas Tarumanagara, Jl.Letjen S. Parman No.1 Jakarta \\ Email: basukia@ft.untar.ac.id
}

\begin{abstract}
ABSTRAK
Keberhasilan suatu proyek konstruksi dapat dilihat berdasarkan ketepatan waktu yang telah dijadwalkan, ketepatan standar mutu, dan ketepatan biaya yang telah dianggarkan. Salah satu faktor penting pada keberhasilan proyek adalah faktor eksternal, dimana faktor eksternal tersebut mempengaruhi durasi proyek konstruksi dan dapat menyebabkan keterlambatan proyek. Tujuan dari penelitian ini adalah untuk mengetahui apakah penggunaan variabel fungsi bangunan sebagai variabel dummy berpengaruh terhadap durasi proyek konstruksi, bersamaan dengan faktor eksternal yang telah diidentifikasi. Penyebaran kuisioner dan pengambilan data teknis proyek ongoing dilakukan pada wilayah Jakarta dan sekitarnya. Analisis faktor dan analisis regresi linier berganda dilakukan untuk menguji hubungan faktor eksternal terhadap durasi estimasi proyek konstruksi. Hasil analisis regresi menunjukkan bahwa hanya variabel PDB dan suku bunga yang berpengaruh secara signifikan terhadap durasi proyek konstruksi. Peningkatan hasil koefisien determinasi pada analisis regresi menggunakan variabel dummy sebesar $10.75 \%$ menandakan bahwa variabel dummy yang dipakai pada penelitian ini, yaitu fungsi bangunan juga berpengaruh terhadap durasi proyek konstruksi.
\end{abstract}

Kata kunci:faktor eksternal terukur, durasi estimasi, analisis faktor, analisis regresi multivariat, variabel dummy.

\section{PENDAHULUAN}

\section{Latar Belakang}

Pada era global saat ini, industri konstruksi berkembang dengan pesat, terutama konstruksi bangunan. Dengan berkembangnya kondisi ekonomi serta teknologi yang semakin global ini, pembangunan pada proyek konstruksi semakin rumit dan kompleks. Ketidakpastian dalam pembangunan proyek menyebabkan pentingnya mengidentifikasi faktor-faktor pengaruh keberhasilan proyek untuk mencegah terjadinya hal-hal yang tidak diinginkan. Bagi para ahli yang terlibat dalam sebuah proyek, keberhasilan proyek merupakan salah satu pencapaian dari beberapa tujuan proyek yang telah ditentukan. Proyek dapat dikatakan sukses apabila proyek tersebut selesai tepat waktu, sesuai ruang lingkup dan bujet yang telah ditentukan.

Salah satu contoh penyebab eksternal yang dapat merugikan proyek konstruksi dikemukakan oleh Gebrehiwet dan Luo (2017) juga menyatakan bahwa korupsi, inflasi atau kenaikan harga bahan, kinerja dan manajemen yang buruk dalam proyek merupakan faktor pengaruh yang menyebabkan keterlambatan proyek. Hal itu menegaskan bahwa faktor eksternal yang merupakan salah satu faktor kesuksesan sebuah proyek, dapat mempengaruhi durasi proyek dan menyebabkan keterlambatan proyek. Di Indonesia, Trigunarsyah (2004) mengidentifikasi bahwa hanya 47\% proyek yang diselesaikan tepat waktu, 15\% lebih cepat, dan 38\% lebih lama dari waktu yang telah ditentukan. Oleh karena itu, sangat penting adanya studi mengenai faktor-faktor penyebab keterlambatan sebuah proyek agar proyek tersebut dapat dikatakan sukses dengan selesai tepat waktu.

Dalam permasalahan ini, analisis regresi dapat dipakai untuk menganalisis keterkaitan antara faktor pengaruh eksternal dengan durasi. Analisis regresi dapat menyatakan keterkaitan atau hubungan antara 2 variabel, 1 variabel sebagai variabel terikat (respon) dan 1 variabel lainnya sebagai variabel bebas (predictor) (Chairunnisa: 2016). Salah satu keterbatasan dari analisis linier berganda yaitu hanya mengakomodasi data kuantitatif dan variabel eksplanatorik. Variabel indikator atau variabel dummy digunakan untuk mewakili prediktor kualitatif (Sousa et al.: 2014). Variabel ini juga digunakan untuk mengetahui pengaruh variabel independen kualitatif terhadap durasi. Variabel dummy dapat meningkatkan kualitas penelitian, atau dapat menghasilkan korelasi yang lebih tinggi (Sousa 
et al.: 2014). Penggunaan variabel dummy merupakan variabel-variabel kualitatif yang dirubah menjadi variabel kuantitatif berupa angka yang terdiri dari 0 (nol) dan 1 .

Pada penelitian ini, digunakan variabel dummy pada analisis regresi linier berganda. Hal ini dilakukan untuk mengetahui seberapa besar pengaruh antara faktor pengaruh eksternal terhadap durasi. Dengan mengetahui hubungan dan pengaruh antara variabel-variabel tersebut, diharapkan manajemen proyek dapat meningkatkan kewaspadaan pada faktor-faktor tersebut selama proyek berlangsung agar meminimalisir terjadinya keterlambatan proyek.

\section{Maksud dan Tujuan Penelitian}

Maksud dari penelitian ini adalah melakukan survei untuk memperoleh faktor pengaruh eksternal terukur yang mempengaruhi durasi proyek dan melakukan analisis hubungannya terhadap durasi dengan metode multivariat regresi. Sedangkan tujuan dari penelitian ini adalah untuk mengetahui manfaat pengaruh penambahan variabel dummy pada nilai determinasi persamaan analisis multivariat faktor eksternal terukur terhadap durasi proyek konstruksi di Jakarta.

\section{Batasan Masalah}

Masalah pada penelitian ini hanya dibatasi oleh beberapa hal seperti, indikator dan data teknis proyek diperoleh dari kuisioner, besaran nilai indikator diperoleh dengan cara pengambilan data melalui website Badan Pusat Statistik, Global Innovation Index, dan World Economic Forum, dan penelitian ini difokuskan pada proyek konstruksi gedung bertingkat.

\section{DASAR TEORI}

\section{Faktor Pengaruh Eksternal}

Faktor eksternal merupakan karakteristik dari lingkungan dan objek-objek yang terlibat didalamnya. Dimana elemen-elemen tersebut dapat mempengaruhi durasi proyek konstruksi. Faktor eksternal terdiri dari indikatorindikator yang menjadi tolak ukur pembangunan disuatu negara. Menurut Djojohadikusumo (1994), faktor eksternal dari kinerja sektor pembangunan dijabarkan terdiri dari atas faktor ekonomi, sumber daya manusia, dan teknologi. Menurut Boediono (2009), faktor-faktor yang mempengaruhi pertumbuhan suatu negara adalah faktor ekonomi yang berpengaruh terhadap investasi di bidang konstruksi, kualitas sumber daya manusianya, dan tingkat teknologi yang digunakan. Faktor - faktor tersebut dapat menjadi dasar untuk meningkatkan kinerja pada sektor konstruksi. Kinerja proyek dapat diukur dan dievaluasi menggunakan sejumlah besar indikator kinerja yang terkait dengan berbagai kelompok seperti waktu, biaya, kualitas, kepuasan klien, perubahan klien, kinerja bisnis, kesehatan dan keselamatan kerja (Cheung et al.: 2004). Oleh karena itu, dapat disimpulkan bahwa kinerja proyek berpengaruh terhadap durasi proyek konstruksi.

Kesuksesan sebuah proyek tidak jauh dari pengaruh waktu durasi proyek konstruksi. Menurut Aziz (2013) dan Luu et al. (2009), mereka juga setuju bahwa waktu merupakan parameter terpenting dari sebuah proyek dan berpengaruh terhadap keberhasilan proyek. Oleh karena itu pada penelitian ini, dilakukan studi literatur untuk mengidentifikasi faktor-faktor pengaruh eksternal terhadap durasi sebagai elemen kinerja proyek konstruksi. Berdasarkan hasil identifikasi tersebut dilakukan pengelompokan 3 variabel laten utama yang akan diteliti dalam penelitian ini, yaitu Variabel Ekonomi, Variabel Sumber Daya Manusia, dan Variabel Teknologi.

\section{Variabel Dummy}

Dalam eksplanatori variabel, terkadang terdapat data kualitatif yang mempengaruhi perhitungan regresi (seperti contohnya pendidikan, gender, dll). Sousa et al. (2014) menyatakan bahwa durasi proyek konstruksi tidak hanya berpengaruh pada kuantitatif variabel tetapi juga kualitatif. Indikator variabel, biasa disebut sebagai variabel dummy, merupakan analisis yang dapat merubah variabel kualitatif menjadi kuantitatif. Variabel ini termasuk binary variable. Faktor-faktor kualitatif dapat dimasukkan ke dalam analisis regresi dengan menggunakan indikator variabel. Variabel kualitatif yang dianalisis mengasumsikan nilai 1 atau 0 (Santoso: 2001).

Variabel dummy sering digunakan pada regresi dan diskriminan analisis. Dimana koefisiennya memiliki interpretasi langsung. Sedangkan penggunaan variabel dummy pada teknik multivariat lainnya lebih terbatas, terutama pada analisis yang mengandalkan pola korelasi seperti analisis faktor karena korelasi dari variabel biner tidak dipresentasikan secara baik oleh koefisien korelasi Pearson (Hair et al.: 1998). 


\section{METODOLOGI PENELITIAN}

\section{Identifikasi Faktor Eksternal Berdasarkan Literatur Terdahulu}

Studi literatur adalah serangkaian cara atau kegiatan yang dilakukan peneliti untuk mencari referensi teori yang berkaitan dengan topik atau permasalahan yang akan diteliti. Dalam penelitian ini, digunakan teknik studi literatur untuk mencari faktor-faktor eksternal apa saja yang mempengaruhi durasi. Studi literatur ini sendiri dilakukan dari berbagai jurnal. Setelah dilakukan studi literatur terhadap jurnal faktor eksternal, peneliti melakukan identifikasi faktor eksternal terukur. Dalam hal ini, dicari variabel faktor eksternal terukur mana saja yang diperlukan untuk menguji keterkaitan dengan durasi proyek. Dari hasil identifikasi tersebut, dipilih 3 grup faktor yang akan diteliti yaitu faktor Ekonomi, faktor Sumber Daya Manusia, dan faktor Teknologi. Kemudian, dilakukan kembali identifikasi literatur untuk mendapatkan faktor eksternal terukur yang akan digunakan pada kuisioner.

\section{Metode Penyusunan Kuisioner}

Penyusunan kuisioner dilakukan setelah didapatkan faktor eksternal terukur yang mempengaruhi durasi. Faktor eksternal tersebut merupakan bahan-bahan untuk penyusunan kuisioner ini. Kuisioner ini dibuat dengan menggunakan skala linkert. Skala likert merupakan skala yang dapat dipergunakan untuk mengukur sikap, pendapat, dan persepsi seseorang atau sekelompok orang tentang suatu gejala atau fenomena pendidikan (Djaali: 2008). Dengan kata lain, skala likert digunakan untuk mengukur atau menilai pilihan yang berjenjang. Variabel yang diukur dalam skala likert dijabarkan menjadi indikator variabel. Lalu indikator variabel tersebut digunakan untuk menjadi dasar atau titik tolak untuk menyusun instrumen berupa pernyataan dalam kuisioner ini. Skala likert yang dipakai pada penelitian ini yaitu 1. Sangat tidak berpengaruh, 2. Sedikit mempunyai pengaruh, 3. Cukup mempunyai Pengaruh, 4. Banyak mempunyai pengaruh, 5. Sangat mempunyai pengaruh.

\section{Metode Distribusi dan Pengumpulan Data}

Kuisioner yang telah dibuat tersebut disebarkan ke proyek-proyek bangunan tinggi yang berada di Jakarta dan sekitarnya. Dikumpulkan juga beberapa data proyek yang dibutuhkan dalam penelitian ini, seperti jumlah lantai, luas lantai, dan durasi proyek.

\section{Metode Pengolahan Data}

\section{Analisis Faktor}

Analisis faktor digunakan untuk mereduksi variabel yang diteliti dan menghasilkan dimensi atau variabel baru, tetapi tetap mampu mempresentasikan variabel utama. Pada penelitian ini, digunakan explanatory factor analysis, yaitu teknik di mana faktor yang akan terbentuk berupa variabel yang belum dapat ditentukan sebelum analisis dilakukan. Tujuan dari explanatory factor analysis ini untuk menemukan hubungan antarvariabel baru, sehingga dapat dibuat kelompok variabel laten baru yang lebih sedikit dari jumlah variabel awal. Beberapa asumsi yang harus terpenuhi dalam analisis faktor yaitu: uji KMO, uji Bartlett, uji MSA, dan uji reabilitas.

\section{Analisis Regresi Multivariat}

Johnson dan Wichern (2007) menyatakan bahwa model regresi linier multivariat adalah model regresi linier dengan lebih dari satu variabel respon (Y) yang saling berkorelasi dan satu atau lebih variabel prediktor (X). Pada penelitian ini, dipakai analisis regresi linier berganda, yaitu analisis yang merupakan pemanjangan dari analisis regresi sederhana. Konsep dan prosedur yang mendasari analisis regresi linier berganda mencakup lebih dari satu prediktor, sehingga regresi berganda menggabungkan beberapa variabel independen dalam membuat prediksi y. Regresi berganda menjelaskan variasi total y, sehingga seringkali memberikan perkiraan yang lebih tepat daripada regresi sederhana. Keuntungan dari pemakaian regresi berganda yaitu mencakup analisis korelasi yang mempertimbangkan bagaimana beberapa variabel berhubungan satu sama lain.

Uji kelayakan dilakukan untuk mengetahui apakah model regresi linier yang telah diolah memang layak untuk menjelaskan pengaruh variabel independen terhadap variabel dependen. Dalam hal penelitian ini, tes kelayakan digunakan memastikan apakah variabel faktor-faktor eksternal yang ditinjau berpengaruh secara signifikan terhadap durasi konstruksi. Pengujian yang dilakukan dalam penelitian ini diantaranya: uji keterandalan model (uji F), uji koefisien determinasi $\left(\mathrm{R}^{2}\right)$, uji multikolinieritas, dan uji autokorelasi.

\section{Analisis Regresi Multivariat dengan Variabel Dummy}

Analisis hubungan dengan variabel dummy dilakukan apabila analisis regresi telah memenuhi seluruh persyaratan. Analisis ini dilakukan dengan menambahkan variabel-variabel kualitatif yang dianggap berpengaruh terhadap durasi 
proyek konstruksi. Dalam penelitian yang dilakukan oleh Sousa et al. (2014) disebutkan bahwa tipe bangunan dan jalanan merupakan kualitatif independent variabel yang paling sering digunakan untuk variabel dummy. Oleh karena itu, diambil klasifikasi tipe bangunan untuk variabel dummy dalam penelitian ini. Ada 4 tipe bangunan yang telah diidentifikasi untuk penelitian ini, yaitu apartemen, perkantoran, hotel, dan lainnya.

Jumlah dari variabel dummy yang dipakai untuk analisis adalah sebanyak $(k-1)$, karena satu variabel tersebut merupakan intercept untuk base group variabel dummy. Apabila semua variabel dimasukkan kedalam persamaan regresi, akan terjadi multikolinieritas sempurna dan program regresi tidak akan berjalan (Maddala: 1992).

\section{ANALISIS DAN PEMBAHASAN}

\section{Identifikasi Faktor Eksternal Terukur}

Dari hasil studi literatur yang telah dilakukan, diambil 3 grup variabel yang akan diteliti yaitu variabel Ekonomi, Sumber Daya Manusia, dan Teknologi. Dari kelompok variabel tersebut diidentifikasi kembali untuk diketahui faktor-faktor apa saja yang mempengaruhi durasi konstruksi melalui studi literatur. Hasil identifikasi faktor eksternal terukur dapat dilihat pada tabel 1.

Tabel 1. Hasil Identifikasi Studi Literatur

\begin{tabular}{|c|c|c|c|}
\hline No & Judul Jurnal & Variabel & Faktor eksternal \\
\hline 1 & $\begin{array}{c}\text { Analysis of Delay Impact on Construction } \\
\text { Project Based on RII and Correlation } \\
\text { Coefficient: Empirical Study (Gebrehiwet dan } \\
\text { Luo: 2017) }\end{array}$ & $\begin{array}{l}\text { Ekonomi, } \\
\text { Teknologi, } \\
\text { SDM }\end{array}$ & $\begin{array}{l}\text { Inflasi, kenaikan harga material, } \\
\text { ketersediaan teknologi }\end{array}$ \\
\hline 2 & $\begin{array}{c}\text { Analyzing Delay Causes in Egyptian } \\
\text { Construction Project (Marzouk dan El-Rass: } \\
\text { 2011) }\end{array}$ & $\begin{array}{l}\text { Ekonomi, } \\
\text { SDM, } \\
\text { Teknologi }\end{array}$ & $\begin{array}{c}\text { Ketersediaan tenaga kerja, pekerja yang } \\
\text { tidak memenuhi syarat, fluktuasi mata } \\
\text { uang, ketersediaan peralatan }\end{array}$ \\
\hline 3 & $\begin{array}{c}\text { Critical Success Factors for Different } \\
\text { Components of Construction Projects (Kog dan } \\
\text { Loh: 2012) }\end{array}$ & $\begin{array}{l}\text { SDM, } \\
\text { Ekonomi }\end{array}$ & $\begin{array}{l}\text { Resiko ekonomi, SDM terutama } \\
\text { kualitas kontraktor dan konsultan }\end{array}$ \\
\hline 4 & $\begin{array}{c}\text { Delay and Cost Overrun in Infrastructure } \\
\text { Projects in Jordan (Al-Hazim, Salem, Ahmad: } \\
\text { 2017) }\end{array}$ & $\begin{array}{l}\text { SDM, } \\
\text { Ekonomi }\end{array}$ & $\begin{array}{c}\text { Ketersediaan tenaga kerja, fluktuasi } \\
\text { harga material }\end{array}$ \\
\hline 5 & $\begin{array}{c}\text { Factor Affecting International Construction } \\
\text { (Gunhan dan Arditi: 2005). }\end{array}$ & $\begin{array}{l}\text { SDM, } \\
\text { Ekonomi }\end{array}$ & $\begin{array}{l}\text { Ketersediaan tenaga kerja, inflasi, } \\
\text { fluktuasi mata uang }\end{array}$ \\
\hline 6 & $\begin{array}{c}\text { Factor Affecting the Performance of } \\
\text { Construction Projects in Gaza Strip (Enshassi, } \\
\text { Mohamed, Abushaban: 2009). }\end{array}$ & $\begin{array}{l}\text { SDM, } \\
\text { Ekonomi, } \\
\text { Teknologi }\end{array}$ & $\begin{array}{c}\text { Ketersediaan tenaga kerja, pengalaman } \\
\text { tenaga kerja, kenaikan harga material, } \\
\text { peralatan }\end{array}$ \\
\hline 7 & $\begin{array}{l}\text { Identification and Assessment of Risk Factors } \\
\text { Affecting Construction Projects (El-Karim, El } \\
\text { Nawawy, Abdel-Alim: 2017) }\end{array}$ & $\begin{array}{l}\text { SDM, } \\
\text { Ekonomi, } \\
\text { Teknologi }\end{array}$ & $\begin{array}{l}\text { Ketersediaan tenaga kerja, pengalaman } \\
\text { tenaga kerja, fluktuasi harga, nilai tukar }\end{array}$ \\
\hline 8 & $\begin{array}{l}\text { Model Development for Estimating Probabilistic } \\
\text { Project Duration using Quantify External Factor } \\
\text { Influence. (Anondho et al.: 2015) }\end{array}$ & $\begin{array}{l}\text { SDM, } \\
\text { Ekonomi, } \\
\text { Teknologi }\end{array}$ & $\begin{array}{c}\text { PDB, nilai tukar, suku bunga, } \\
\text { pendidikan, ketersediaan tenaga kerja, } \\
\text { teknologi }\end{array}$ \\
\hline
\end{tabular}

Dari hasil identifikasi yang telah dilakukan, faktor eksternal terukur yang digunakan dalam penelitian ini yaitu:

1. Variabel Ekonomi: kenaikan harga material, nilai tukar, suku bunga, inflasi, dan PDB.

2. Variabel SDM: tingkat pendidikan, ketersediaan tenaga kerja, tingkat kesehatan, pengalaman tenaga kerja.

3. Variabel Teknologi: penyerapan teknologi, ketersediaan teknologi baru, dan inovasi.

\section{Distribusi dan Pengumpulan Data}

Kuisioner yang telah dihasilkan kemudian didistribusikan ke beberapa proyek pada wilayah Jakarta dan sekitarnya. Responden dari kuisioner ini merupakan Project Manager, Site Manager, dan Site Engineer. Sebanyak 53 responden dari 14 proyek konstruksi yang meengembalikan kuisioner. Sedangkan data dokumentasi untuk faktor 
eksternal terukur didapatkan dari BPS, WEF, dan Global Innovation Index. Dikumpulkan juga 43 buah arsip data proyek berupa durasi, jumlah lantai, dan luas lantai dari proyek on-going. Data-data tersebut digunakan untuk menganalisis hubungan antara faktor eksternal dan durasi estimasi menggunakan analisis regresi dengan menyertakan jumlah dan luas lantai proyek.

\section{Pengolahan Data}

Pengolahan data dalam penelitian ini dibagi menjadi 3 tahap, yaitu analisis faktor, analisis regresi multivariat, dan analisis regresi multivariat menggunakan dummy variabel. Untuk memudahkan penelitian, faktor-faktor eksternal terukur menggunakan notasi seperti yang dapat dilihat pada tabel 2. Semua analisis pada penelitian ini menggunakan software SPSS ${ }^{\circledR}$. Hasil dari penelitian akan dijabarkan sebagai berikut.

Tabel 2. Notasi Faktor Eksternal Terukur

\begin{tabular}{cccc}
\hline Notasi & Faktor Eksternal Terukur & Notasi & Faktor Eksternal Terukur \\
\hline X1 & Inflasi & Y2 & Pengalaman kerja \\
\hline X2 & Harga material & Y3 & Pendidikan \\
\hline X3 & Produk Domestik Bruto & Y4 & Kesehatan \\
\hline X4 & Nilai tukar & Z1 & Ketersediaan teknologi baru \\
\hline X5 & Suku bunga & Z2 & Penyerapan teknologi \\
\hline Y1 & Ketersediaan Sumber Daya Manusia & Z3 & Inovasi \\
\hline
\end{tabular}

\section{Analisis Faktor}

Pada analisis faktor ini dilakukan uji validitas data dan reabilitas data. Uji validitas dilakukan untuk mengetahui kecukupan data sedangkan reabilitas data dilakukan untuk mengetahui apakah data yang diperoleh reliabel atau tidak. Setelah semua asumsi terpenuhi, dilakukan pengelompokkan faktor untuk mengetahui kelompok faktor baru yang akan digunakan pada analisis regresi multivariat. Hasil dari uji MSA menyatakan bahwa nilai tukar (X4) dan ketersediaan sumber daya manusia (Y1) tidak memenuhi persyaratan karena nilai uji MSA kurang dari 0.5. Oleh karena itu, kedua faktor tersebut direduksi dan dilakukan kembali analisis ulang. Setelah dilakukan analisis ulang, dapat dilihat pada tabel 3 uji KMO dan uji Bartlett memenuhi persyaratan karena nilai uji KMO berada diatas 0.5 dan nilai uji Bartlett berada dibawah 0.05. Nilai pada uji MSA pun memenuhi persyaratan karena semua faktor memiliki nilai diatas 0.5. Sedangkan nila pada uji reabilitas menggunakan Cronbach's Alpha pada tabel 4 memenuhi persyaratan karena nilai melebihi syarat minimal dari Cronbach’s Alpha.

Tabel 3. Hasil Iterasi 2 Uji KMO dan Uji Bartlett

\begin{tabular}{|c|c|c|}
\hline Kaiser-Meyer-Olkin Measure & of Sampling Adequac & .668 \\
\hline & Approx. Chi-Square & 207.034 \\
\hline Bartlett's Test of Sphericity & Df & 45 \\
\hline & Sig. & .000 \\
\hline
\end{tabular}

Tabel 4. Hasil Uji Reabilitas

\begin{tabular}{cc}
\hline Cronbach's Alpha & N of Items \\
\hline .773 & 10 \\
\hline
\end{tabular}

Setelah semua asumsi terpenuhi, dapat dilakukan pengelompokkan faktor baru yang tidak saling berkorelasi. Terdapat 3 kelompok faktor baru yang terbentuk seperti yang dapat dilihat pada tabel 5. Dari tabel loading faktor diatas, dapat dilihat seberapa besar variabel-variabel berkorelasi dengan faktor yang terbentuk. Penentuan kelompok faktor dengan cara melihat korelasi terbesar dari variabel tersebut. Maka anggota dari kelompok faktor yang terbentuk adalah: Kelompok 1: Z2 (penyerapan teknologi), Z3 (inovasi), Z1 (ketersediaan teknologi baru), Y2 (pengalaman kerja), Y3 (pendidikan), Y4 (kesehatan); Kelompok 2: X3 (PDB), X5 (suku bunga); Kelompok 3: X1 (inflasi), X2 (harga material). 
Tabel 5. Hasil Loading Faktor

\begin{tabular}{cccc}
\hline & \multicolumn{3}{c}{ Component } \\
\cline { 2 - 4 } & 1 & 2 & 3 \\
\hline $\mathrm{Z} 2$ & .854 & .046 & -.015 \\
$\mathrm{Z} 3$ & .846 & -.037 & -.022 \\
$\mathrm{Z} 1$ & .784 & .076 & -.051 \\
$\mathrm{Y} 2$ & .676 & .161 & .196 \\
$\mathrm{Y} 3$ & .612 & .517 & .071 \\
$\mathrm{Y} 4$ & .604 & -.147 & .585 \\
$\mathrm{X} 3$ & .008 & .841 & .187 \\
$\mathrm{X} 5$ & .136 & .837 & -.020 \\
$\mathrm{X} 1$ & .033 & .069 & .854 \\
$\mathrm{X} 2$ & -.103 & .480 & .626 \\
\hline
\end{tabular}

\section{Analisis Regresi Multivariat}

Pada penelitian ini, analisis regresi multivariat dilakukan untuk menguji kelayakan (Goodness of Fit) dari data yang telah didapatkan oleh peneliti. Data tersebut berasal dari: BPS (suku bunga, inflasi, PDB, harga material, pengalaman tenaga kerja), WEF (pendidikan, penyerapan teknologi, ketersediaan teknologi baru, kesehatan), dan Global Innovation Index (inovasi). Peneliti akan membahas satu persatu mengenai hasil dari analisis regresi yang telah dilakukan pada 3 kelompok yang telah didapatkan dari analisis faktor sebelumnya.

\section{A. Hasil Analisis Kelompok 1}

Dapat dilihat pada tabel 6 bahwa nilai VIF pada kolom Collinearity Statistics menunjukkan adanya multikolinieritas. Multikolinieritas adalah sejauh mana variabel dapat dijelaskan oleh variabel lainnya dalam analisis. Model dapat dikatakan terdapat multikolinieritas apabila nilai VIF berada diatas 10. Semakin meningkatnya multikoliniearitas, maka semakin sulit untuk menginterpretasikan variat karena lebih sulit untuk memastikan efek dari setiap variabel (Hair et al.: 1998).

Tabel 6. Coefficients Kelompok 1

\begin{tabular}{lccccc}
\hline \multirow{2}{*}{ Model } & \multicolumn{2}{c}{ Unstandardized Coefficients } & Standardized Coefficients & \multicolumn{2}{c}{ Collinearity Statistics } \\
\cline { 2 - 6 } & $B$ & Std. Error & Beta & Tolerance & VIF \\
\hline (Constant) & .010 & .009 & & & \\
Y3 & -160.740 & 97.082 & -5.713 & .001 & 1161.270 \\
Z2 & 72.678 & 63.142 & 2.992 & .002 & 658.956 \\
Z1 & 96.486 & 54.184 & 3.969 & .002 & 484.625 \\
Z3 & 1.226 & 2.615 & .328 & .021 & 47.675 \\
Y4 & -1.470 & 1.265 & -.858 & .019 & 53.253 \\
\hline
\end{tabular}

a. Dependent Variable: DURASI

Karena terjadi multikolinieritas, Hal tersebut melanggar asumsi kaidah klasik pada analisis regresi. Oleh karena itu, analisis tidak dapat dilanjutkan karena model tidak memenuhi syarat dari regresi liniear berganda. Dapat dikatakan bahwa model regresi tidak dapat dipakai untuk penelitian.

\section{B. Hasil Analisis Kelompok 2}

Nilai determinasi (R2) pada tabel 7 menyatakan bahwa 54.9\% durasi dapat dijelaskan oleh variabel X3 dan X5, yaitu PDB dan harga material. Sedangkan sisanya dijelaskan oleh sebab-sebab yang lain. Dapat dilihat juga nilai untuk Durbin-Watson adalah 1.719. Uji Durbin-Watson dilakukan untuk mendeteksi adanya autokorelasi pada penelitian. Autokorelasi merupakan salah satu uji asumsi klasik pada analisis faktor untuk mengetahui apakah model terdapat korelasi dengan perubahan waktu. Santoso (2012) menyatakan apabila nilai Durbin-Watson terletak diantara -2 sampai +2, maka tidak terdapat autokorelasi. Karena angka dari Durbin-Watson $<2$, maka dapat dikatakan bahwa tidak terdapat autokorelasi positif dan autokorelasi negatif pada model. 
Tabel 7. Model Summary Kelompok 2

\begin{tabular}{cccccc}
\hline Model & $\mathrm{R}$ & $\mathrm{R}$ Square & $\begin{array}{c}\text { Adjusted } R \\
\text { Square }\end{array}$ & $\begin{array}{c}\text { Std. Error of the } \\
\text { Estimate }\end{array}$ & Durbin-Watson \\
\hline 1 & $.741^{\mathrm{a}}$ & .549 & .526 & .03104 & 1.719 \\
\hline
\end{tabular}

a. Predictors: (Constant), X3, X5

b. Dependent Variable: DURASI

Pada tabel 8, hasil dari F hitung adalah 24.346, dengan signifikansi 0.00. karena F hitung (24.346) < F tabel (4.08), dan nilai signifikansi $<0.05$, maka $\mathrm{H}_{0}$ ditolak, atau dapat dikatakan bahwa variabel X3 dan X5 secara simultan (bersama-sama) berpengaruh secara signifikan terhadap durasi.

Tabel 8. ANOVA Kelompok 2

\begin{tabular}{llccccc}
\hline Model & & Sum of Squares & $\mathrm{df}$ & Mean Square & $\mathrm{F}$ & Sig. \\
\hline \multirow{4}{*}{1} & Regression & .047 & 2 & .023 & 24.346 & $.000^{\mathrm{b}}$ \\
& Residual & .039 & 40 & .001 & & \\
& Total & .085 & 42 & & & \\
\hline
\end{tabular}

a. Dependent Variable: DURASI

b. Predictors: (Constant), X3, X5

Tabel 9. Coefficients Kelompok 2

\begin{tabular}{llcccc}
\hline \multirow{2}{*}{ Model } & \multicolumn{2}{c}{ Unstandardized Coefficients } & Standardized Coefficients & \multicolumn{2}{c}{ Collinearity Statistics } \\
\cline { 2 - 6 } & $\mathrm{B}$ & Std. Error & Beta & Tolerance & VIF \\
\hline (Constant) & .011 & .009 & & & \\
1 & 18.988 & 5.309 & 1.106 & .118 & 8.477 \\
X5 & -.001 & .001 & -.402 & .118 & 8.477 \\
\hline
\end{tabular}

a. Dependent Variable: DURASI

Pada tabel 9 diatas, menunjukkan persamaan regresi: $\mathrm{Y}=-0.011+18.988$ X5 -0.001 X3. Arti dari persamaan tersebut ialah:

- Konstanta sebesar -0.011 menyatakan bahwa jika tidak ada PDB dan suku bunga, maka durasinya adalah -0,011 minggu x jumlah lantai/m2.

- Koefisien regresi X5 (suku bunga) sebesar 18.988 menyatakan bahwa setiap kenaikan suku bunga sebesar satu satuan, maka durasi akan naik sebesar 18.988 minggu x jumlah lantai/m2. Dapat dikatakan, semakin tinggi suku bunga, semakin lama durasi dari proyek tersebut

- Koefisien regresi X3 (PDB) sebesar -0.001 menyatakan bahwa setiap kenaikan dari PDB satu satuan, maka durasi akan turun sebesar -0,001 minggu x jumlah lantai/m2, dengan asumsi variabel bebas yang lain dari model regresi adalah tetap. Hal ini menyatakan bahwa semakin besar PDB, semakin cepat durasi dari suatu proyek.

Pada kolom Colliniearity Statistics, nilai dari VIF adalah 8.477. karena nilai tersebut kurang dari 10, maka dapat dikatakan bahwa model regresi tidak terjadi multikoliniearitas dan dapat dianalisis lebih lanjut. Hasil dari analisis regresi pada kelompok 2 menunjukkan semua uji kelayakan terpenuhi. Oleh karena itu, kelompok 2 dapat dianalisis lebih lanjut menggunakan variabel dummy.

C. Hasil Analisis Kelompok 3

Tabel 10. Coefficients Kelompok 3

\begin{tabular}{cccccc}
\hline \multirow{2}{*}{ Model } & \multicolumn{2}{c}{ Unstandardized Coefficients } & \multicolumn{2}{c}{ Standardized Coefficients } & \multicolumn{2}{c}{ Collinearity Statistics } \\
\cline { 2 - 6 } & $\mathrm{B}$ & Std. Error & Beta & Tolerance & VIF \\
\hline (Constant) & .016 & .009 & & & \\
$1 \mathrm{X} 1$ & -.560 & 4.358 & -.033 & .182 & 5.493 \\
$\mathrm{X} 2$ & .288 & .099 & .749 & .182 & 5.493 \\
\hline \multicolumn{2}{c}{ a. Dependent Variable: DURASI }
\end{tabular}

Tabel 10 menunjukkan persamaan regresi $\mathrm{Y}=0.016-0.560 \mathrm{X} 1+0.288 \mathrm{X} 2$ yang memiliki arti sebagai berikut:

- Konstanta sebesar 0.016 menyatakan bahwa jika tidak ada inflasi dan harga material, maka besarnya durasi adalah 0.016 minggu x jumlah lantai/m2. 
- Koefisien regresi X1 (inflasi) sebesar -0.560 menyatakan bahwa setiap kenaikan inflasi sebesar satu satuan, maka durasi akan turun sebesar -0.560 dengan asumsi variabel bebas yang lain dari model regresi adalah tetap.

- Koefisien regresi X2 (PDB) sebesar 0.288 menyatakan bahwa setiap kenaikan dari harga material sebesar satu satuan, maka durasi akan turun sebesar 0.288 dengan asumsi variabel bebas yang lain dari model regresi adalah tetap. Hal ini menyatakan bahwa semakin tinggi harga material, durasi proyek akan semakin lama.

Pada hasil dari analisis kelompok 3, model persamaan regresi menyatakan bahwa semakin tinggi inflasi maka durasi akan semakin cepat. Karena hal tersebut tidak mungkin terjadi, maka model pada kelompok ini tidak dapat digunakan pada penelitian selanjutnya.

\section{Analisis Regresi Multivariat dengan Variabel Dummy}

Analisis hubungan dengan variabel dummy dapat dilakukan apabila kelompok variabel indikator telah memenuhi persyaratan analisis regresi multivariat. Pada penelitian ini, dilakukan analisis dengan menggunakan variabel dummy pada kelompok 2. Kelompok 1 tidak dapat dianalisis karena tidak memenuhi persyaratan uji asumsi klasik dari analisis regresi (terdapat multikolinieritas), sedangkan model pada kelompok 3 tidak dapat digunakan karena koefisien persamaan regresi yang tidak benar.

Dalam variabel dummy ini, diambil 4 variabel independen baru dari tipe bangunan yaitu apartemen, perkantoran, hotel, dan bangunan lainnya. Pengelompokkan untuk variabel dummy dapat dilihat pada tabel 11. Karena jumlah variabel dummy yang digunakan untuk analisis adalah $(k-1)$, maka tipe bangunan lainnya digunakan sebagai base grup (D1, D2, dan D3 ditetapkan sebagai nol) dan tidak dimasukkan pada analisis regresi multivariat. Pola koding yang akan digunakan pada analisis regresi multivariat dapat dilihat pada tabel 12.

Tabel 11. Tabel Pengelompokkan Variabel Dummy

\begin{tabular}{cc}
\hline Tipe Bangunan & Variabel Dummy \\
\hline Apartemen & D1 $=1$, selain D1 $=0$ \\
\hline Perkantoran & D2 $=1$, selain D2 $=0$ \\
\hline Hotel & D3 $=1$, selain D3 $=0$ \\
\hline Bangunan Lainnya & D4 $=1$, selain D4 $=0$ \\
\hline
\end{tabular}

Tabel 12. Pola Koding Variabel Dummy

\begin{tabular}{cccc}
\hline Koefisien/ Variabel Dummy & D1 & D2 & D3 \\
\hline Apartemen & 1 & 0 & 0 \\
\hline Perkantoran & 0 & 1 & 0 \\
\hline Hotel & 0 & 0 & 1 \\
\hline Bangunan Lainnya & 0 & 0 & 0 \\
\hline
\end{tabular}

Setelah itu, variabel dummy tersebut dimasukkan pada analisis regresi bersamaan dengan PDB dan suku bunga sebagai independen variabel. Hasil dari analisis regresi multivariat menggunakan variabel dummy pada kelompok 2 akan dijabarkan sebagai berikut.

Tabel 13. Model Summary

\begin{tabular}{lccccc}
\hline Model & $\mathrm{R}$ & $\mathrm{R}$ Square & Adjusted R Square & Std. Error of the Estimate & Durbin-Watson \\
\hline 1 & $.780^{\mathrm{a}}$ & .608 & .555 & .03009 & 1.862 \\
\hline a. Predictors: (Constant), D3, X3, D2, D1, X5 & & \\
b. Dependent Variable: DURASI
\end{tabular}

Tabel 13 menunjukkan angka dari $\mathrm{R}^{2}$ memiliki arti 60.8\% variabel independen dapat menjelaskan variabel dependen. Sedangkan sisanya yaitu 39.2\% dipengaruhi oleh variabel lain diluar penelitian. Sedangkan angka dari uji autokorelasi Durbin-Watson (d) adalah 1.862. Karena angka $\mathrm{d}<2$, maka tidak terjadi autokorelasi positif dan negatif. Hal ini menyatakan bahwa waktu tidak mempengaruhi nilai dari persamaan tersebut. 
Tabel 14. ANOVA

\begin{tabular}{llccccc}
\hline Model & & Sum of Squares & $d f$ & Mean Square & F & Sig. \\
\hline \multirow{4}{*}{1} & Regression & .052 & 5 & .010 & 11.474 & $.000^{\mathrm{b}}$ \\
& Residual & .034 & 37 & .001 & & \\
& Total & .085 & 42 & & & \\
\hline
\end{tabular}

a. Dependent Variable: DURASI

b. Predictors: (Constant), D3, X3, D2, D1, X5

F hitung pada tabel 14 adalah 11.474, dengan signifikansi 0.00. Karena F hitung jauh lebih besar dari F tabel (2.62), dan probabilitas lebih kecil dari 0.05, maka Ho ditolak dan H1 diterima. Dapat disimpulkan bahwa variabel PDB dan suku bunga bersama-sama berpengaruh terhadap durasi.

Tabel 15. Coefficients

\begin{tabular}{cccccc}
\hline \multirow{2}{*}{ Model } & \multicolumn{2}{c}{ Unstandardized Coefficients } & Standardized Coefficients & \multicolumn{2}{c}{ Collinearity Statistics } \\
\cline { 2 - 6 } & $\mathrm{B}$ & Std. Error & Beta & Tolerance & VIF \\
\hline (Constant) & -.012 & .017 & & & \\
X5 & 15.704 & 5.371 & .914 & .108 & 9.231 \\
X3 & -.001 & .001 & -.225 & .109 & 9.149 \\
1 D1 & .026 & .017 & .287 & .300 & 3.336 \\
D2 & .036 & .018 & .363 & .319 & 3.134 \\
D3 & .006 & .022 & .039 & .539 & 1.856 \\
\hline
\end{tabular}

a. Dependent Variable: DURASI

Persamaan regresinya dari tabel 15 adalah: $\mathrm{Y}=-0.012+15.704 \mathrm{X} 5-0.001 \mathrm{X} 3+0.026 \mathrm{D} 1+0.036 \mathrm{D} 2+0.006 \mathrm{D} 3$. Persamaan regresi tersebut memiliki arti sebagai berikut:

- Konstanta sebesar -0.012 menyatakan bahwa jika tidak ada variabel independen, maka besarnya durasi adalah 0.012 minggu x jumlah lantai/m2.

- Koefisien regresi X5 sebesar 15.704 menyatakan bahwa setiap kenaikan suku bunga sebesar satu satuan, maka durasi akan naik sebesar 15,704, dengan asumsi variabel bebas yang lain dari model regresi adalah tetap. Dapat dikatakan, semakin tinggi suku bunga, semakin lama durasi dari proyek tersebut

- Koefisien regresi X3 sebesar - 0.001 menyatakan bahwa setiap kenaikan dari PDB satu satuan, maka durasi akan turun sebesar - 0.001 dengan asumsi variabel bebas yang lain dari model regresi adalah tetap. Hal ini menyatakan bahwa semakin besar PDB, semakin cepat durasi dari suatu proyek.

- Koefisien regresi D1 sebesar 0.026 menyatakan bahwa ada pengaruh apartment sebagai fungsi bangunan sebesar 1 satuan dikalikan dengan koefisien persamaan regresinya, apabila konstruksinya adalah bangunan apartement, dengan D2, dan D3 = 0 .

- Koefisien regresi D2 sebesar 0.036. Hal ini mengandung arti bahwa ada pengaruh perkantoran sebagai fungsi bangunan sebesar 1 satuan dikalikan dengan koefisien persamaan regresinya, apabila konstruksinya adalah bangunan perkantoran, dengan D1, dan D3 = 0 .

- Koefisien regresi D3 sebesar 0.006 menyatakan bahwa ada pengaruh hotel sebagai fungsi bangunan sebesar 1 satuan dikalikan dengan koefisien persamaan regresinya, apabila konstruksinya adalah bangunan apartement, dengan D1, dan D2 = 0 .

Pada Colliniearity Statistics, nilai dari VIF secara keseluruhan berada dibawah 10. Oleh karena itu, dapat dikatakan bahwa model regresi tidak terjadi multikoliniearitas.

\section{KESIMPULAN}

Dari hasil penelitian, dapat ditarik beberapa kesimpulan sebagai berikut:

1. Dari hasil pengurangan faktor pada data kuisioner menggunakan analisis faktor, didapatkan 10 faktor eksternal terukur yang berpengaruh terhadap durasi. Setelah itu, didapatkan 3 kelompok variabel eksternal terukur baru. Kelompok tersebut adalah:

- Kelompok 1: tingkat pendidikan, tingkat kesehatan, pengalaman tenaga kerja, penyerapan teknologi, ketersediaan teknologi baru, dan inovasi.

- Kelompok 2: PDB dan suku bunga

- Kelompok 3: inflasi dan harga material 
Masing-masing dari kelompok tersebut dilihat pengaruhnya terhadap perkiraan durasi. Hasil dari analisis regresi menunjukkan bahwa model pada kelompok 1 dan kelompok 3 tidak akurat karena model pada kelompok 1 terdapat multikolinieritas dan model pada kelompok 3 tidak dapat digunakan.

2. Berdasarkan hasil analisis regresi multivariat sebelum menggunakan variabel dummy, hanya model pada kelompok 2 yang memenuhi persyaratan regresi. Oleh karena itu, digunakan model kelompok 2 sebagai analisis hubungan prediksi durasi dengan variabel suku bunga dan pdb. Nilai dari koefisien determinasi $\left(\mathrm{R}^{2}\right)$ pada analisis sebesar 0.549. Artinya, faktor eksternal PDB dan suku bunga berpengaruh terhadap durasi sebesar 54.9\%. Hasil tersebut tidak cukup baik sehingga dibutuhkan variabel dummy untuk meningkatkan nilai determinasi.

3. Penggunaan penambahan variabel dummy pada hasil persamaan regresi hubungan durasi dengan variabel suku bunga dan pdb, meningkatkan koefisien determinasi $\left(\mathrm{R}^{2}\right)$ sebesar 0.601 atau peningkatan sebesar $10.75 \%$ pada koefisien determinasi. Hal ini menunjukkan bahwa fungsi bangunan juga berpengaruh terhadap durasi disamping PDB dan suku bunga.

\section{DAFTAR PUSTAKA}

Aziz, Remon Fayek. (2013). "Ranking of delay factors in construction projects after Egyptian revolution”. Alexandria Engineering Journal. Vol. 52: 387-406.

Boediono. (2009). Ekonomi Indonesia, Mau ke Mana? Jakarta: Kepustakaan Populer Gramedia.

Chairunnisa, Rizka. (2016). Model Perkiraan Durasi Akhir Proyek dengan Luas Lantai Menggunakan Earned Value Method and Analisis Regresi. Skripsi. Universitas Tarumanagara.

Cheung, S.-O., H. C. H. Suen, and K. K. W. Cheung. (2004). "PPMS: A Web-based construction project performance monitoring system”. Automation in Construction. Vol. 13: 361-376.

Djaali. (2008). Psikologi Pendidikan. Jakarta: Bumi Aksara.

Djojohadikusumo, Sumitro. (1994). Perkembangan Pemikiran Ekonomi: Dasar Teori Ekonomi Pertumbuhan and Ekonomi Pembangunan. Jakarta: PT Pustaka LP3ES Indonesia.

Gebrehiwet, Tsegay and Hanbin Luo. (2017). “Analysis of delay impact on construction project based on RII and correlation coefficient: empirical study”. Procedia Engineering. Vol. 196: 366-374.

Hair, Joseph F., et al. (1998). Multivariate Data Analysis. New Jersey: Prentice-Hall, Inc.

Johnson, R. A. and Wichern, D. (2007). Applied Multivariate Statistical Analysis. New Jersey: Prentice Hall.

Luu, Van Truong, Soo-Yong Kim, and S. Ogunlana. (2009). "Quantifying schedule risk in construction projects using Bayesian belief networks”. International Journal of Project Management. Vol. 27: 39-50.

Maddala, G.S. (1992). Introduction to Econometrics: $2^{\text {nd }}$ Edition. New York: Macmillan Publishing Company.

Santoso, Singgih. (2001). SPSS Versi 10: Mengolah Data Statistik Secara Profesional. Jakarta: PT Elex Media Komputindo.

Santoso, Singgih. (2012). Panduan Lengkap SPSS Versi 20. Jakarta: PT Elex Media Komputindo.

Sousa, Vitor, Nuno Marques Almeida, and Luis Alves Dias. (2014). "Role of statistics and engineering judgment in developing optimized time-cost relationship models”. Journal of Construction Engineering and Management. Vol. 140: 04014034.

Trigunarsyah, B. (2004). “Constructability practices among construction contractors in Indonesia”. Journal of Construction Engineering and Management. Vol. 130: 656-665. 